\title{
Foreword to the Van Aarde Festschrift
}

\begin{abstract}
Author:
Johan Buitendag ${ }^{1,2}$

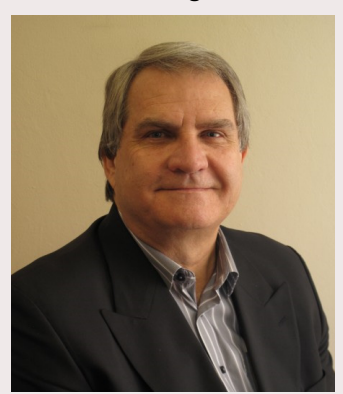

Affiliations:

${ }^{1}$ Dean of the Faculty of Theology, University of

Pretoria, South Africa

${ }^{2}$ Department of Dogmatics and Christian Ethics, University of Pretoria, South Africa

email:

johan.buitendag@up.ac.za

Postal address:

Faculty of Theology,

University of Pretoria,

Private Bag X20, Hatfield

0028, South Africa

How to cite this article:

Buitendag, J., 2011,

'Foreword to the Van

Aarde Festschrift', HTS

Teologiese Studies/

Theological Studies 67(1)

Art. \#1038, 2 pages. DOI:

10.4102/hts.v67i1.1038

Note:

This foreword was

republished on 14 June

2011.
\end{abstract}

(C) 2011. The Authors. Licensee: OpenJournals Publishing. This work is licensed under the Creative Commons Attribution License.

\section{Voorwoord ter erkenning van Andries van Aarde}

Gesien vanuit die perspektief van die Universiteit van Pretoria in die algemeen en van die Fakulteit Teologie in die besonder, is dit verblydend dat erkenning op hierdie manier aan ' $n$ begaafde teoloog en eksegeet gegee word. Ek ag dit 'n eer en voorreg om die voorwoord tot hierdie Festschrift te mag skryf.

Vir byna die volle duur van professor Andries Gideon van Aarde se professionele loopbaan was hy in diens van die Universiteit van Pretoria, aanvanklik as lektor en later as departementshoof. Al sy naskoolse kwalifikasies (onder andere drie doktorsgrade) het hy van hierdie inrigting ontvang. $\mathrm{Na}$ sy vervroegde emeritaat is hy by die Universiteit van Pretoria as honorêre professor in die Departement Nuwe-Testamentiese Wetenskap en as senior navorsingsgenoot in die Eenheid vir Gevorderde Studies aangestel. Selfs ' $n$ vlugtige blik op sy navorsingsportefeulje toon watter prolifieke skrywer hy deur die jare was. Hiervoor het hy wêreldwyd hoë erkenning ontvang. Hy het ook 'n groot aantal doktorale studente gedurende sy loopbaan begelei.

Andries word in die besonder geëer vir sy bydrae tot die uitbouing van die HTS Teologiese Studies. As redakteur sedert 1985 het hy HTS ontwikkel tot een van die mees toonaangewende vakwetenskaplike joernale in die teologie in Suid-Afrika vandag. Hy het die leiding geneem om die tydskrif aanlyn te laat publiseer en het daarmee waarskynlik die lesertal en effek van die HTS verhonderdvoudig. Die HTS het tans ongeveer ' $\mathrm{n}$ halfmiljoen besoekers per jaar van regoor die wêreld, veral vanuit lande soos die VSA, Duitsland en Nederland.

Kollegas het besondere waardering vir Andries se intra- en selfs interdissiplinêre aanslag in sy teologie. Hy slaag daarin om sy komprehensiewe greep op ' $n$ komplekse wêreld te konseptualiseer en kommunikeer. Daarom is sy teologie en eksegese van antieke tekste dinamies en kragtig. Hy is oortuig dat navorsing gedissemineer behoort te word. Hoewel hy self ' $n$ professionele teoloog is,

\section{Foreword in recognition of Andries van Aarde}

From the perspective of the University of Pretoria in general and of the Faculty of Theology in particular, it is gratifying that recognition is given in this way to a gifted theologian and exegete. I deem it an honour and privilege to write the foreword to this publication.

For most of Professor Andries Gideon van Aarde's professional career he was in the employ of the University of Pretoria, initially as lecturer and eventually as head of department. He received all his tertiary qualifications (including three doctoral degrees) from this institution. After his early retirement, he was appointed honorary professor in the Department of New Testament Studies. Even a quick glance at his research portfolio reveals what a prolific writer he has been over the years. He has received national and international recognition and has supervised a large number of doctoral students during his career.

Andries is also honoured for his invaluable contribution to the HTS Theological Studies. As editor since 1985, he has developed HTS into one of the leading theological journals in South Africa today. He took the initiative for publishing the journal online and thereby greatly increased the number of readers and the impact of HTS. At present HTS has about half a million visitors per year from across the world, especially from countries such as the United States, Germany and the Netherlands.

Andries' intra-disciplinary and even interdisciplinary approach to theology is especially appreciated by his peers. He succeeds in conceptualising and effectively communicating his comprehensive view on the complexities of reality. His theology and exegesis of ancient writings are dynamic and powerful. He is adamant that research results should be disseminated. Although he is a professional theologian, Andries has appreciation for what he considers to be public theology. With this concept he refers to God who speaks through poets, artists, film directors and others in the market square. $\mathrm{He}$ likes to dialogue with scholars of disciplines other than theology without striving towards synthesis or consenting to antithesis. He prefers a dialectic discourse. 
het hy waardering vir publieke teologie. Met hierdie begrip bedoel hy dat God ook deur digters, kunstenaars, filmmakers en ander op die markplein praat. Hy voer graag dialoog met ander wetenskaplikes, dikwels buite die teologie om, maar sonder om te streef na sintese of te berus by antitese. Hy gee voorkeur aan dialektiese diskoers.

Andries erken die voorlopigheid van alle kennis en daarmee saam die mens se onvermoë om ewige waarhede te identifiseer en as proposisies voor te hou. Hy beskou hom eerder as 'n oop-dialektiese teoloog in die Kantiaanse sin van die woord. In Schleiermacheriaanse sin word partikulariteit by hom ' $n$ kenteoretiese voorwaarde, maar nooit so dat hy daarmee volstaan nie. 'Versoenende verskeidenheid', wat hom 'die ander wang laat draai', is die begrip waarmee hy self sy epistemologiese posisie beskryf en hom laat uitreik na die gemarginaliseerdes in die samelewing.

Die Redaksie van die HTS Teologiese Studies vind 'n waardige laureatus in Andries en soos wat hierdie feesbundel hom tot eer strek, gebeur ook die omgekeerde: hý gee eer aan die HTS Teologiese Studies.

Prof. Dr Johan Buitendag

Dekaan van die Fakulteit Teologie, Universiteit van Pretoria, Suid-Afrika
Andries acknowledges the provisional nature of knowledge and the inability of humanity to identify eternal truths and proclaim them as fixed dogmatic propositions. He can be regarded as an open-dialectical theologian in the Kantian sense of the word. In the Schleiermacherian sense of the word particularity becomes for Andries an epistemological condition, but never to the extent that it suffices. 'Reconciliatory diversity' describes his epistemological position which allows him to turn the 'other cheek' and reach out to those who have been marginalised in society.

The Editorial Staff of the HTS Theological Studies found a worthy laureate in Andries. This HTS Festschrift bestows honour to him as he does to HTS.

Prof. Dr Johan Buitendag

Dean of the Faculty of Theology, University of Pretoria, South Africa 